\title{
Refusal to Participate
}

National Cancer Institute

\section{Source}

National Cancer Institute. Refusal to Participate. NCI Thesaurus. Code C124784.

Declining to take part in activities or procedures that are available to, or requested or expected of, an individual. 